\title{
Structural Relationship Between Psychological Disorders, Quality of Life and Coping Styles among Brain Disorder Patients
}

\section{Priscilla Das*}

Unit of Biostatistics \& Research Methodology, School of Medical Sciences Universiti Sains Malaysia 16150 Kubang Kerian Kelantan,

Malaysia

Faculty of Health Sciences, Asia Metropolitan University, G-8, Jalan Kemacahaya 11, Taman Kemacahaya, Batu 9, 43200 Cheras, Selangor Darul Ehsan,

Malaysia

\section{Nyi Nyi Naing}

Institute for Community (Health) Development (i-CODE), Universiti Sultan Zainal Abidin, Gong Badak Campus, 21300 Kuala Nerus, Terengganu, Malaysia

\section{Nadiah Wan-Arfah}

Institute for Community (Health) Development (i-CODE), Universiti Sultan Zainal Abidin, Terengganu, Malaysia

\section{KON Noorjan}

Departmentof Psychiatry, Faculty of Medicine and Health Sciences, Universiti Putra Malaysia Malaysia

\section{Yee Cheng Kueh}

Unit of Biostatistics \& Research Methodology, Department of Psychiatry, School of Medical Sciences Universiti Sains Malaysia 16150 Kubang Kerian Kelantan,

Malaysia

\section{Kantha Rasalingam}

Department of Neuroscience, Hospital Kuala Lumpur 50586 Jalan Pahang Kuala Lumpur Malaysia

*Corrosponding author's Email: daspriscilla@yahoo.com

Peer-review under responsibility of $4^{\text {th }}$ Asia International Conference 2018 editorial board (http://www.utm.my/asia/our-team/) (C) 2018 Published by Readers Insight Publisher, lat 306 Savoy Residencia, Block 3 F11/1,44000 Islamabad. Pakistan, info@readersinsight.net

This is an open access article under the CC BY-NC-ND license (http://creativecommons.org/licenses/by-nc-nd/4.0/). 


\section{Research High Iights}

Brain tumour are rare cases that account for only $2 \%$ and worldwide it affect 7 per 100,000 population annually (Arber, Faithfull, Plaskota, Lucas, \& de Vries, 2010; Parkin, Whelan, \& J., 2005). Furthermore the cancer is one of the leading causes of death worldwide (Ferlay, et al., 2015). The most common primary brain tumours are the astrocytomas, oligodendrogliomas, and ependymomas which arise from the glial origin followed by meningiomas, schwannomas, craniopharyngiomas, germ cell tumors, pituitary adenomas, and pineal region tumors from non-glial origin. About half of all brain tumors are gliomas (Price, Goetz, \& Lovell, 2007) and in Peninsular Malaysia alone, the malignant gliomas are reported to account for $34.6 \%$, followed by medulloblastoma $11.3 \%$ and meningothelial tumours $3.1 \%$ of all nervous system tumours (Lim, Rampal, \& Halimah, 2008)

\section{Graphical A bstract}

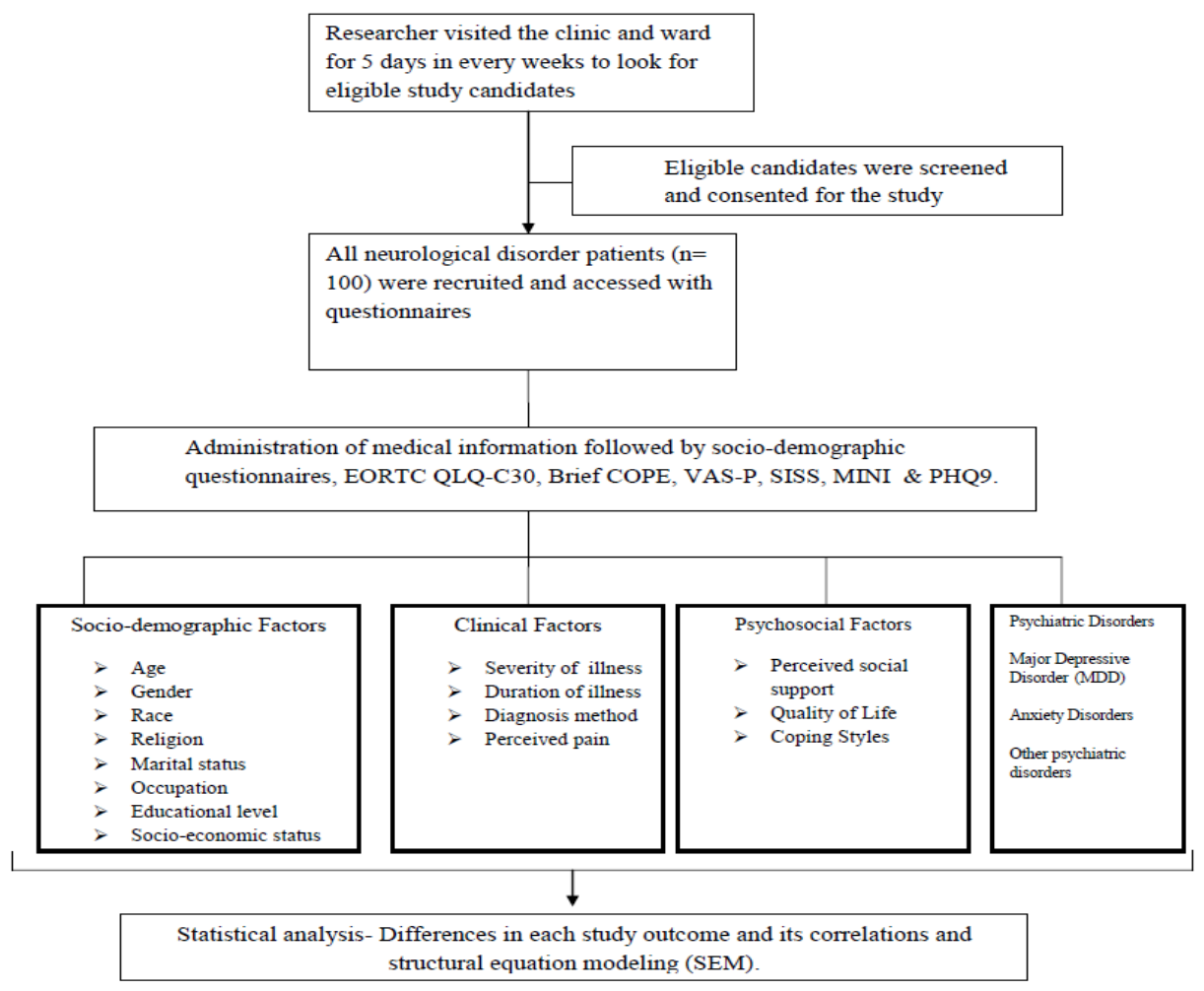




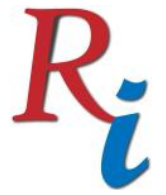

Asia Proceedings of Social Sciences

(APSS)

www.readersinsight.net/APSS

\section{Research Objectives}

The study intends to model the structural relationship of MDD, anxiety disorders, other psychiatric disorders, quality of life, coping styles and their associated factors among neurological disorder (brain tumour / brain disorder) patients.

\section{Methodology}

The EORTC-Quality of Life, Brief COPE, Single Item Social Support, MINI International Neuropsychiatric Interview and Patient Health Questionnaires were utilised in the study. The Statistical Package for Social Sciences (SPSS) programme version 22 and Amos version 24 were used to analyse the data obtained in the study. SEM -Path analyses were done for interrelationship between the parameters. In all cases, $\mathrm{p}<0.05$ denoted statistical significance.

\section{Results}

The multivariate normality kurtosis was 6.174 with c.r $=2.440$ obtained in this SEM model.

Chi-square normalized by degrees of freedom, $\left(\chi_{\circ}^{2} / \mathrm{df}\right)=1.086, \mathrm{p}=0.353$. The RMSEA was 0.03 , TLI $=0.988$ and CFI $=0.999$ were obtained in the study. All 8 paths out of 10 paths were significant with p-values less than 0.05 (two-tailed) with $\mathrm{R} 2$ values ranging from 0.48 to 0.55 which indicates that the variance explained ranged from $48 \%$ for emotional functioning to $55 \%$ for severity of depression. The severity of MDD has positive relationship with insomnia and panic disorder lifetime and negative relationship with self distraction coping styles. Meanwhile emotional functioning had negative relationship with fatigue, venting and panic disorder lifetime and positive relationship with global health status. The emotional functioning also was correlated negatively with the severity of MDD $(\mathrm{p}<0.005)$. 


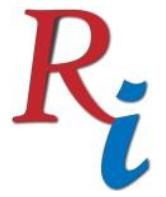

\section{Asia Proceedings of Social Sciences (APSS) \\ www.readersinsight.net/APSS}

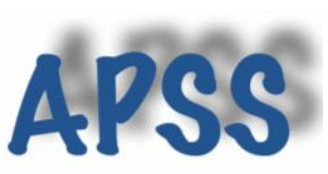

\section{Findings}

The emotional functioning of the patients were influenced by the fatigue, global health status, venting coping styles and panic disorder lifetime and this increased the severity of MDD among the patients. Therefore the role of quality of life and coping styles on depression and anxiety should not be neglected. The clinician, health psychologist, psychiatrist, and counselor in this country need to implement better treatments for the effected patients. Conclusion: Therefore based on the path analysis, the main contributing factors of MDD severity were emotional functioning, insomnia, self distraction coping and panic disorder lifetime.

\section{Acknowledgement}

The study supported by USM Short Term Grant, Project no: 304/PPSP/6315007 and Priscilla Das has been awarded with MyBrain15-MyPhd scholarship from Ministry of Education of Malaysia.

\section{References}

Arber, A., Faithfull, S., Plaskota, M., Lucas, C., \& de Vries, K. (2010). A study of patients with a primary malignant brain tumour and their carers: symptoms and access to services. Int J Palliat Nurs, 16(1), 24-30.

Ferlay, J., Soerjomataram, I., Dikshit, R., Eser, S., Mathers, C., Rebelo, M., et al. (2015). Cancer incidence and mortality worldwide: sources, methods and major patterns in GLOBOCAN 2012. Int J Cancer, 136(5), E359-386.

Lim, G., Rampal, S., \& Halimah, Y. (2008). Cancer incidence in Penisular Malaysia, 20032005. National Cancer Registry, Kuala Lumpur.

Parkin, D. M., Whelan, S. L., \& J., F. (2005). Cancer incidence in five continents. International Agency for Research on Cancer: Lyon, vol. I to VIII. IARC Cancerbase No 7.

Price, T. R., Goetz, K. L., \& Lovell, M. R. (2007). Neuropsychiatric Aspects of Brain Tumors. In: Yudofsky SC, Hales RE, editors. (The American Psychiatric 
Asia Proceedings of Social Sciences (APSS)

www.readersinsight.net/APSS

Publishing Textbook of Neuropsychiatry and Behavioral Neurosciences 5th ed. Arlington, VA ed.): American Psychiatric Publishing. 